\title{
MODERN APPROACHES TO THE MODEL ANALYSIS OF THE CAPSULATE FUNCTIONAL PRODUCT BASED ON THE SEA BUCKTHORN OIL
}

\author{
Современные подходы к моделированию капсулированного \\ функционального продукта на основе облепихового масла
}

\author{
Koshelev Yu.A., Vereschagin A.L., Goremykina N.V. \\ Кошелев Ю.А., Верещагин А.Л., Горемыкина Н.В.
}

\author{
Keywords: \\ sea buckthorn oil; \\ soft sugarplums; \\ carotenoids; \\ triglycerides
}

\section{Ключевые слова: облепиховое масло; мягкое драже; каротиноиды; триглицериды}

\begin{abstract}
The article is devoted to the challenging topic aimed at expanding the foodstuff range based on the sea buckthorn oil as a source of essential polyunsaturated fatty acids ( $\omega-3$, $\omega-6$ and $\omega-7)$, phospholipids, and other biologically active substances and vitamins. As a research result the product recipes on the basis of the concentrated sea buckthorn oil, soft sugarplums "Sea Buckthorn Oil" were developed. The optimum ratio of the main raw, materials, to achieve high organoleptic indicators of sugarplums are the following: $51.23 \mathrm{~g}$ of sugar, $8.2 \mathrm{~g}$ of the concentrated sea buckthorn oil, $32.8 \mathrm{~g}$ of the refined sunflower oil рег $100 \mathrm{~g}$ respectively. The conditions and storage periods of the developed sugarplums are determined: during the selected standard storage mode at the temperature $t=18 \pm 3^{\circ} \mathrm{C}$ and the saturation ratio less than $75 \%$ the sugarplums in a sealed package can be stored for 12 months from the date of production. As the fundamental quality indicators, the regulated quality indicators of the soft sugarplums as well as the biologically active substances amount that determines the functional properties of the developed sugarplums were developed. The results display that 6 soft sugarplums "Sea Buckthorn Oil" is able to meet $30 \%$ of the daily needs in carotenoids. It allows to recommend the sugarplum as a tonic remedy for all consumer categories.
\end{abstract}

\section{Реферат}

Статья посвящена актуальной теме расширения ассортимента пищевых продуктов на основе использования облепихового масла как источника незаменимых полиненасыщенных жирных кислот ( $\omega-3, \omega-6$ и $\omega-7)$, фосфолипидов и других биологически активных веществ и витаминов.

По результатам исследований разработаны рецептуры продуктов на основе концентрата масла облепихи крушиновидной - мягкое драже «Облепиховое масло». С целью достижения высоких органолептических показателей драже установлено оптимальное соотношение основного сырья, г/100 г: сахар-песок - 51,23; концентрат облепихового масла - 8,2; масло подсолнечное рафинированное - 32,8. Определены условия и сроки хранения разработанных драже: при выбранном стандартном режиме хранения ( $t=18 \pm 3{ }^{\circ} \mathrm{C}$; OBВ - не более $75 \%$ драже в герметичной упаковке могут храниться в течение 12 месяцев с даты производства. За основополагающие приняты регламентируемые показатели качества мягкого драже, а также содержание биологически активных веществ (БАВ), обусловливающих функциональные свойства разработанных драже.

Полученные результаты показывают, что шесть мягких драже «Облепиховое масло» способны удовлетворять 30 \% суточной потребности в каротиноидах, что позволяет рекомендовать их в качестве общеукрепляющего средства для всех категорий потребителей. 


\section{Relevance}

The sea buckthorn oil is known to be a natural concentrate of carotenoids, tocopherols, phylloquinones, phytosterols, polyunsaturated fatty acids ( $\omega-3, \omega-6$ and $\omega-7)$, phospholipids, and other biologically active substances and vitamins, it is manufactured remedy with the different therapeutic properties harmful side-effects devoid [1].

The research purpose is to develop the CPL soft sugarplums based on the sea buckthorn oil concentrate.

As the research results and run monitoring of the functional confectionery products based on sea buckthorn oil market $[2,3]$, an innovative product - CPL soft sugarplums "Sea Buckthorn Oil" that are based on the soft gelatin capsule filled with homogeneous oily liquid from the concentrate sea buckthorn oil with addition of refined sunflower oil and knurled powdered sugar - is offered. The advantage of the new sugarplums is the following: not all consumers, especially children, like tasteless capsules. In our opinion, developed sugarplums are the new method to deliver to the human body essential fatty acids of the sea buckthorn oil.

The CPL soft sugarplums "Sea Buckthorn Oil" is intended for the realization through the retail network for all population groups. It has the high taste properties and contains essential fatty acids of the sea buckthorn oil as an ingredient.

The Objects and Methods of the Research

The study objects in this project were the laboratory and production samples: the CPL soft sugarplums "Sea Buckthorn oil" produced on the "Altaivitaminy" base, Biysk.

Organoleptic characteristics of the sugarplums samples (shape, appearance, color, taste, flavor, quantity of agglomerated and deformed sugarplums, the number of sugarplums on $1 \mathrm{~kg}$ ) were determined by the visual inspection, tasting and counting according to the GOST 5897-90 [4].
Moisture content of the sugarplums samples were determined by drying to the constant weight according to the GOST 5900-73 [5].

The total acidity was determined by the titration according to the GOST 5898-87[6]. The method is based on the neutralization of the acids contained in the samples, and the sodium hydroxide solution in the presence of phenolphthalein until the pink color appeared. The acidity is expressed in degrees. By the acidity degrees is meant the $\mathrm{cm} 3$ number of the sodium hydroxide $\mathrm{N}$-solution used for the neutralization of acids contained in $100 \mathrm{~g}$ of the sugarplums.

The vitamin $C$ determination was performed by the iodate titration method according to the GOST 7047-55 [7].

Discussion of the Results

The ingredients for the sugarplums recipe were selected on the basis of the chemical sea buckthorn oil concentrate analysis, as well as through the introduction of the necessary for this product form technological additives taking into account quality and safety requirements. For the basic recipe of the soft sugarplums, two variants with different contents of major flavor components (sea buckthorn oil concentrate and sugar) were further prepared. The taste of the three sugarplums formulations is estimated by the 30 point scale [8] (table 1).

The technological process of the CPL soft sugarplums "Sea Buckthorn Oil" production consisting of the steps shown on the figure 1 was developed.

An oily mixture was prepared from the sea buckthorn oil concentrate by diluting it with the sunflower oil and blending (averaging) it in blending reservoir.

On the first stage, the assessment of organoleptic characteristics was carried (table 2).

According to the table 2 , the obtained prototypes meet the requirements of the GOST 7060-79 by

Formulation Value for the Production of the CPL Soft Sugarplums "Sea Buckthorn Oil"

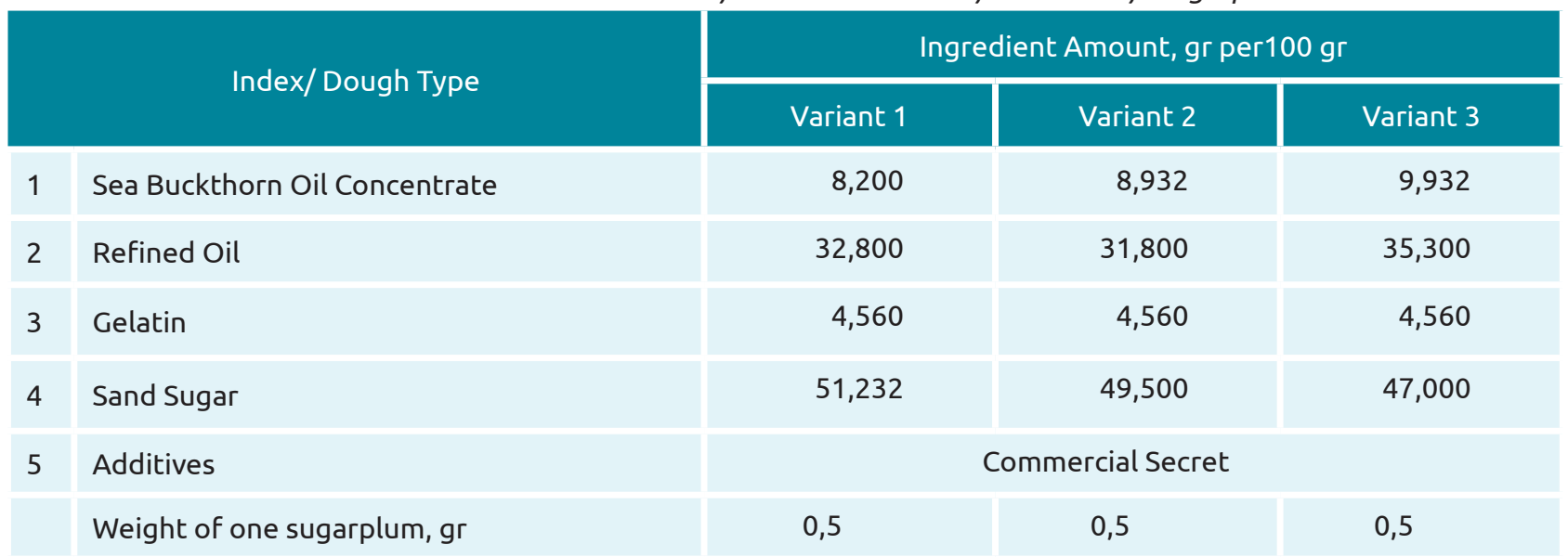




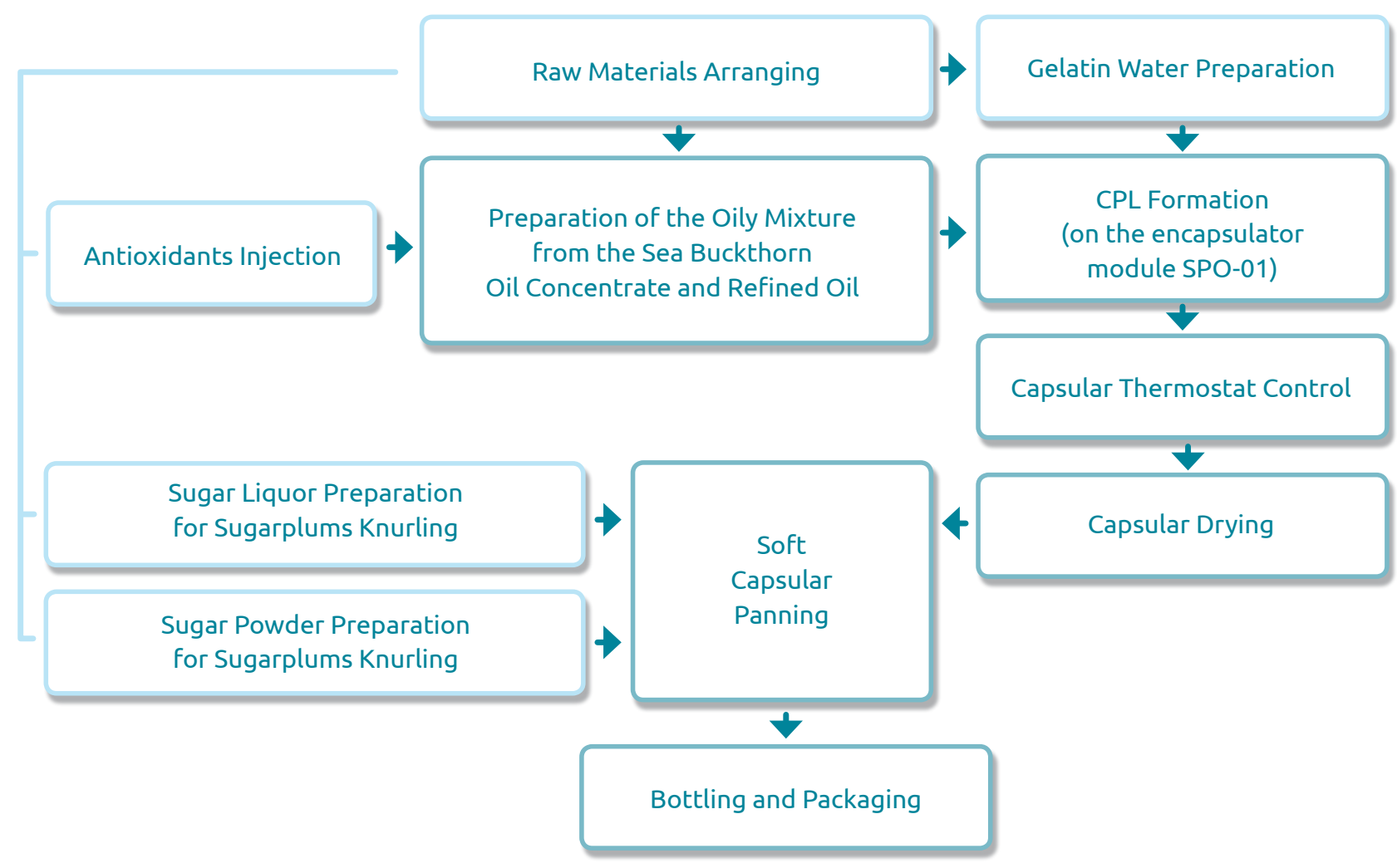

Figure 1. Block diagram of the CPL soft sugarplums production

Table 2

Formulation Value for the Production of the CPL Soft Sugarplums "Sea Buckthorn Oil"

\begin{tabular}{|c|c|c|c|c|}
\hline Exponent & Reference Sample & Variant 1 & Variant 2 & Variant 3 \\
\hline Mode & \multicolumn{4}{|c|}{ Regular, spherical } \\
\hline Layout & $\begin{array}{l}\text { The sugarplums } \\
\text { are soft filled with } \\
\text { homogeneous } \\
\text { syrupy oily moisture }\end{array}$ & \multicolumn{3}{|c|}{$\begin{array}{l}\text { The sugarplums are soft with regular sugar powder coating filled } \\
\text { with homogeneous syrupy oily moisture }\end{array}$} \\
\hline Color & Light-orange & \multicolumn{3}{|c|}{ White } \\
\hline Taste & $\begin{array}{l}\text { Pronounced fruit } \\
\text { (sea buckthorn), } \\
\text { sour enough, short } \\
\text { and sour aftertaste } \\
\text { without flavors-off }\end{array}$ & $\begin{array}{c}\text { Enjoyable, } \\
\text { moderately sweet, } \\
\text { slightly sour, } \\
\text { pronounced fruit } \\
\text { (sea buckthorn), } \\
\text { without flavors-off }\end{array}$ & $\begin{array}{l}\text { Pronounced fruit } \\
\text { (sea buckthorn), too } \\
\text { sour long-lasting } \\
\text { and sour aftertaste } \\
\text { without flavors-off }\end{array}$ & $\begin{array}{l}\text { Pronounced fruit } \\
\text { (sea buckthorn), } \\
\text { sour enough, short } \\
\text { and sour aftertaste } \\
\text { without flavors-off }\end{array}$ \\
\hline Flavour & Low fruit & \multicolumn{3}{|c|}{ Pronounced fruit, enjoyable, fresh } \\
\hline Tasting Score & 23,5 & 30 & 26 & 24 \\
\hline $\begin{array}{l}\text { Number } \\
\text { of Sticked and Strain } \\
\text { Sugarplums, \% } \\
\text { (by Weight) }\end{array}$ & \multicolumn{4}{|c|}{0} \\
\hline $\begin{array}{l}\text { Number } \\
\text { of Sugarplums } \\
\text { in } 1 \mathrm{~kg}, \text { PCS }\end{array}$ & \multicolumn{4}{|c|}{2000} \\
\hline
\end{tabular}


Physical and Chemical Characteristics of the CPL Soft Sugarplums "Sea Buckthorn Oil"

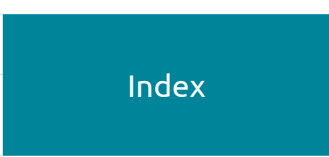

Moisture, \%

Acidity,

Degree, Less than

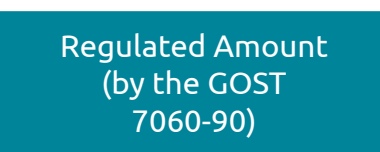

$5,0-9,0$

23,5

No applicable regulation

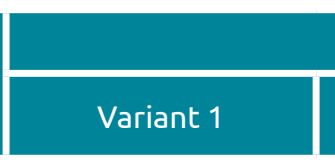

$7,8 \pm 0,1$

30

$4,2 \pm 0,1$
Real Amount

Variant 2

26

$4,4 \pm 0,1$

$4,6 \pm 0,1$ its organoleptic indicators. For the basic formulations, the most optimal ingredients combination (variant 1) giving the most advanced and harmonious taste - pleasant, moderate sweet, with slight acidity, pronounced fruit (sea buckthorn), without off-taste - was selected. The positive influence of the pearl sugar on the organoleptic quality of the CPL soft sugarplums "Sea Buckthorn Oil" is noticed. The degustation evaluation total score of the soft sugarplums "Sea Buckthorn Oil" quality is 8.5 points higher than in the control sample.

Only some of physical and chemical parameters regulated according to the GOST were determined, as developed sugarplums refer to a liqueur according to the type of coat [9] (table 3).

As developed soft sugarplums are positioned as a functional product, the amount of a number of biologically active substances in the sugarplums samples was determined (table 4).
As can be seen from the table 4, the number of glycerides and carotenoids in the soft sugarplums varies insignificantly, whereas sugarplums prepared according to the formulation № 1 are recognized the best by the taste.

By the microbiological and safety indicators, sugarplums should meet the requirements of the TR CU 021/2011 "About the food safety" [10], that is confirmed by the study (tables 5 and 6 ).

The expiry date was carried out by controlling the sugarplums samples embedded for the storage in accordance with the main directives of the MUK 4.2.1847-04 [11]. The products were stored for 14 months at a temperature of $18 \pm 3^{\circ} \mathrm{C}$ and the saturation ratio of $70 \pm 5 \%$, in the consumers hermetically sealed containers - polyethylene food jars with a screw cap weighing 50,0 $\pm 3,0 \mathrm{~g}$. During the storage, organoleptic, physical, chemical and microbiological parameters were defined every 3 months.

Table 4

The Amount of Biologically Active Substances in the CPL soft sugarplums "Sea Buckthorn Oil"

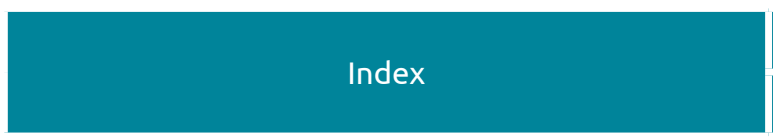

Glyceryl Content, \%

Triolein Content, \%

Tripalmitin Content, \%

Carotenoids Content (calculated as $\beta$-carotin), мr \%

\begin{tabular}{|c|c|c|}
\hline \multicolumn{3}{|c|}{ Amount in 100 gr of Sugarplums } \\
\hline Variant 1 & Variant 2 & Variant 3 \\
\hline $17,46 \pm 1,13$ & $17,38 \pm 1,13$ & $17,40 \pm 1,13$ \\
\hline $60,89,03$ & $60,29,03$ & $60,05,03$ \\
\hline $8,99 \pm 0,05$ & $8,76 \pm 0,05$ & $8,60 \pm 0,05$ \\
\hline $69,00 \pm 2,60$ & $68,50 \pm 2,60$ & $68,20 \pm 2,60$ \\
\hline
\end{tabular}

Table 5

Microbiological Indicators of the CPL Soft Sugarplums "Sea Buckthorn Oil"

\begin{tabular}{|l|l|l|}
\hline \multicolumn{1}{|c|}{ Index } & Variant 1 & Variant 2 \\
\hline QMA\&OAMO, c.f.u. in $1 \mathrm{gr}$ of the Product & Not more than $2,5 \times 103$ & Less than 10,0 \\
\hline Product Weight, $\mathrm{gr}$, in which the Following Is Prohibited: & & Not Detected \\
\hline Coliforms (Poliforms) in $0,1 \mathrm{gr}$ & Not permitted & Not Detected \\
\hline Pathogenic Bacterium Including Salmonella, in $25 \mathrm{gr}$ & Not permitted & Less than 10 \\
\hline Yeast, c.f.u. per $1 \mathrm{gr}$ & Not more than 50,0 & Less than 10 \\
\hline Penicillium, c.f.u. per $1 \mathrm{gr}$ & Not more than 50,0 & \\
\hline
\end{tabular}


Table 6

Safety Indicators of the CPL soft sugarplums "Sea Buckthorn Oil"

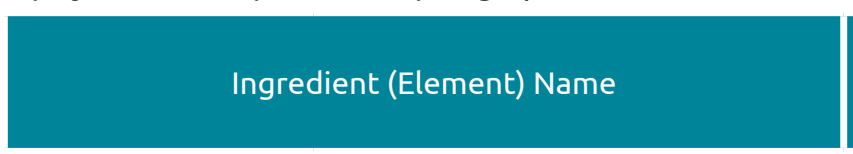

Toxic Component

Pesticide
Plumb

Arsenic

Cadmium

Mercuric

$\mathrm{HCH}(a, \beta, y$-isomere)

DDD and Its Metabolites
Allowable Content Level

(by the TR CU 021/2011),

mg per kg, Not More Than

1,0

1,0

0,1

0,01

0,005

0,005

\begin{tabular}{|c|}
\hline Real Amount \\
\hline 0,09 \\
\hline Less than 0,02 \\
0,003 \\
\hline Less than 0,002 \\
\hline Not Detected \\
\hline Not Detected
\end{tabular}

During the storage period the sugarplums organoleptic and, physical and chemical characteristics are determined not to be changed. Minor changes took place in the physiological value indicators (figure 2): decreased carotenoid number (calculated as B-carotene) to $55.40 \mathrm{mg} \%$, which is about $80 \%$ of the original. The glycerides number has not practically changed, that indicates the optimal conditions for the extraction solvent removal from the sea buckthorn oil concentrate providing the product with increased expiry period.

Summarizing obtained in the process of storing results by organoleptic, physical and chemical, toxicological and microbiological indicators, the biologically active substances amount in the CPL soft sugarplums "Sea Buckthorn Oil" the expiry date is possibly being determined. Under the selected standard storage mode $-\mathrm{t}=18 \pm 3{ }^{\circ} \mathrm{C}$ and the saturation ratio not more than $75 \%$ - sugarplums in a sealed aseptic package can be stored for 12 months from the date of production.
So, sugarplums are able to satisfy $30 \%$ of the daily needs in carotenoids allowing to recommend it as a tonic remedy for all consumer categories.

By the results of the research of the CPL soft sugarplums "Sea Buckthorn Oil" the regulated quality indicators for conducting comprehensive trade analysis of the sugarplums were determined (tables $7,8,9$ and 10$)$.

The serial production of the CPL soft sugarplums "Sea Buckthorn Oil" is arranged on the base of the LC "Altaivitaminy" (Biysk, the Altai territory).

Thus, in the final part of the work according to the research results the functional orientation sugarplums - the CPL soft sugarplums "Sea Buckthorn Oil" based on the sea buckthorn oil concentrate were developed. It implemented at LC "Altaivitaminy". Its mass production continues that will allow to expand the product range at the regional level, which will differ by lower price compared to imported products due to the transport costs reduction and the use of local raw materials.

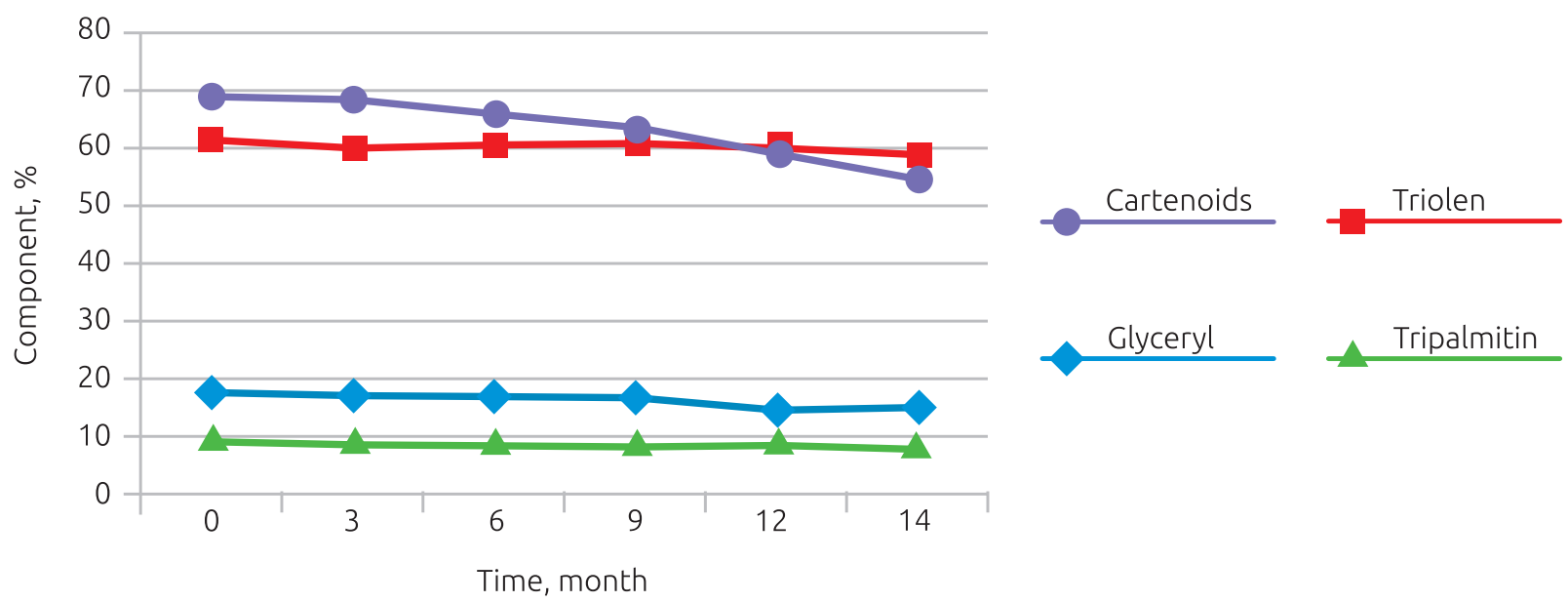

Figure 2. Dynamics of Reducing the Amount of Glyceryl, Triolein, Tripalmitin and Carotenoids in the Soft Sugarplums "Sea Buckthorn Oil" 
Regulated organoleptic and physical and chemical indicators of the soft sugarplums "Sea Buckthorn Oil"

\begin{tabular}{|c|c|}
\hline Exponent & Amount \\
\hline Mode & Regular, spherical \\
\hline Layout & $\begin{array}{l}\text { The sugarplums are soft with regular sugar powder } \\
\text { coating filled with homogeneous syrupy oily moisture }\end{array}$ \\
\hline Color & White \\
\hline Taste & $\begin{array}{l}\text { Enjoyable, moderately sweet, slightly sour, pronounced } \\
\text { fruit (sea buckthorn), without flavors-off }\end{array}$ \\
\hline Flavour & Pronounced fruit, enjoyable, fresh \\
\hline Number of Sticked and Strain Sugarplums, \% (by Weight) & 0 \\
\hline Number of Sugarplums in $1 \mathrm{~kg}, \mathrm{PCS}$ & 2000 \\
\hline Moisture, \% & $5,0-9,0$ \\
\hline Index & Amount in $100 \mathrm{gr}$ of Sugarplums, \% \\
\hline Glyceryl Content, \% & $15 \pm 15$ \\
\hline Triolein Content, \% & $55 \pm 15$ \\
\hline Tripalmitin Content, \% & $8 \pm 15$ \\
\hline Carotenoids Content (calculated as $\beta$-carotin), мг \% & $60 \pm 15$ \\
\hline
\end{tabular}

Table 9 Regulated Microbiological Indicators of the CPL Soft Sugarplums "Sea Buckthorn Oil"

\section{Index}

QMA\&OAMO, c.f.u. in $1 \mathrm{gr}$ of the Product

Product Weight, gr, in which the Following Is Prohibited:

Coliforms (Poliforms) in 0,1 gr

Pathogenic Bacterium Including Salmonella, in $25 \mathrm{gr}$

Yeast, c.f.u. per $1 \mathrm{gr}$

Penicillium, c.f.u. per $1 \mathrm{gr}$
Regulated Amount

Not more than $2,5 \times 103$

Not permitted

Not permitted

Not more than 50,0

Not more than 50,0

Table 10

Regulated Safety Indicators of the CPL soft sugarplums "Sea Buckthorn Oil"

\section{Ingredient (Element) Name}

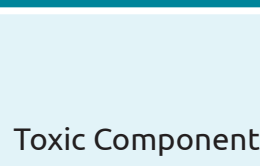

Pesticide
Allowable Content Level, mg per kg, Not More Than

$$
1,0
$$

0,1

0,01

0,005

0,005 


\section{Bibliography}

1. Galieva A.I. Razrabotka i issledovanie potrebitel'skih svojstv obogashhennogo drazhe: avtoref. diss. ... kand. tehn. nauk: 05.18.15. Kemerovo, 2014. $16 \mathrm{~s}$.

2. GOST 5897-90. Izdelija konditerskie. Metody opredelenija organolepticheskih pokazatelej kachestva, razmerov, massy netto i sostavnyh chastej. M.: Standartinform, 2012. S. 11-16.

3. GOST 5898-87. Izdelija konditerskie. Metody opredelenija kislotnosti i shhelochnosti. M.: Standartinform, 2012. S. 18-26.

4. GOST 5900-73. Izdelija konditerskie. Metody opredelenija vlagi i suhih veshhestv. M.: Standartinform, 2012. S. 47-54.

5. GOST 7047-55. Vitaminy A, S, D, V1, V2 i RR. Otbor prob, metody opredelenija vitaminov i ispytanija kachestva vitaminnyh preparatov. M.: Izdatel'stvo standartov, 1994. $48 \mathrm{~s}$.

6. GOST 7060-79. Drazhe. Tehnicheskie uslovija. M.: Standartinform, 2004. S. 51-58.

7. Gur'janov Ju.G., Lobach E.Ju., Reznichenko I.Ju. Ocenka potrebitel'skih predpochtenij k novym produktam funkcional'nogo naznachenija // Polzunovskij vestnik. 2012. № 2/2. S. 187-190.

8. MUK 4.2.1847-04. 4.2. Metody kontrolja. Biologicheskie i mikrobiologicheskie faktory. Sanitarno-jepidemiologicheskaja ocenka obosnovanija srokov godnosti i uslovij hranenija pishhevyh produktov: metod. ukazanija (utv. Glavnym gosudarstvennym sanitarnym vrachom RF 06.03.2004). M., 2004. $18 \mathrm{~s}$.

9. 0 bezopasnosti pishhevoj produkcii: Tehnicheskij reglament Tamozhennogo sojuza 021/2011 (utv. 09.12.2011 g. resheniem komissii Tamozhennogo sojuza). M., 2011. $242 \mathrm{~s}$

10. Poznjakovskij V.M., Reznichenko I.Ju., Guseva I.Ju. Konditerskie izdelija: prakticheskoe i uchebnoe posobie. Kemerovo: KemTIPP, 1999. $51 \mathrm{~s}$.

11. Sea buckthorn: monograph / Yu.A. Koshelev, L.D. Ageeva, E.S. Batashov, V.P. Sevodin, E.D. Rozhnov, N.I. Kuleshova. Biysk: Publishing house of Polzunov Altai State Technical, 2015. 401 p.

\section{Библиографический список}

1. Галиева А.И. Разработка и исследование потребительских свойств обогащенного драже: автореф. дис. ... канд. техн. наук: 05.18.15. Кемерово, 2014. 16 с.

2. ГОСТ 5897-90. Изделия кондитерские. Методы определения органолептических показателей качества, размеров, массы нетто и составных частей. М.: Стандартинформ, 2012. С. 11-16.

3. ГОСТ 5898-87. Изделия кондитерские. Методы определения кислотности и щелочности. М.: Стандартинформ, 2012. С. 18-26.

4. ГОСТ 5900-73. Изделия кондитерские. Методы определения влаги и сухих веществ. М.: Стандартинформ, 2012. С. 47-54.

5. ГОСТ 7047-55. Витамины А, С, Д, В1, В2 и РР. 0тбор про6, методы определения витаминов и испытания качества витаминных препаратов. М.: Изд-во стандартов, 1994. 48 с.

6. ГОСТ 7060-79. Драже. Технические условия. М.: Стандартинформ, 2004. С. 51-58.

7. Гурьянов Ю.Г., Лобач Е.Ю., Резниченко И.Ю. Оценка потребительских предпочтений к новым продуктам функционального назначения // Ползуновский вестник. 2012. № 2/2. С. 187-190.

8. МУК 4.2.1847-04. 4.2. Методы контроля. Биологические и микробиологические факторы. Санитарно-эпидемиологическая оценка обоснования сроков годности и условий хранения пищевых продуктов: метод. указания (утв. Главным государственным санитарным врачом РФ 06.03.2004). М., 2004. 18 c.

9. 0 безопасности пищевой продукции: Технический регламент Таможенного союза 021/2011 (утв. 09.12.2011 г. решением комиссии Таможенного союза). М., 2011. 242 с.

10. Позняковский В.М., Резниченко И.Ю., Гусева И.Ю. Кондитерские изделия: практическое и учебное пособие. Кемерово: КемТИПП, 1999. 51 c.

11. Sea buckthorn: monograph / Yu.A. Koshelev, L.D. Ageeva, E.S. Batashov, V.P. Sevodin, E.D. Rozhnov, N.I. Kuleshova. Biysk: Publishing house of Polzunov Altai State Technical, 2015. 401 p.

\section{Koshelev Yurii Antonovich \\ Кошелев Юрий Антонович}

Тел./Phone: (3854) 43-53-01 E-mail:bt@bti.secna.ru

\section{Vereschagin Alexandr Leonidovich \\ Верещагин Александр Леонидович}

Тел./Phone: (3854) 43-53-18 E-mail:ohet@bti.secna.ru

\section{Goremykina} Natalia Vladimirovna

Горемыкина Наталья Владимировна

Тел./Phone: (3854) 43-53-18 E-mail:goremykina-natali@mail.ru
Doctor of Pharmaceutical Science, Professor

CEO of the LC "Altaivitaminy», Head of the Biotechnology Department Biysk Technological Institute (subdivision) Altai State Technical University of I.I. Polzunov 659305, Russia, Altai Territory, Biysk, Trofimova St., 27

Доктор фармачевтических наук, профессор, генеральный директор ЗАО "Алтайвитамины», заведующий кафедрой биотехнологии Бийский технологический институт - филиал Алтайского государственного технического университета им. И.И. Ползунова 659305, РФ, Алтайский край, г. Бийск, ул. Трофимова, 27

Doctor of Chemical Science, Professor

Head of the General Chemistry and Goods Expertise Department

Biysk Technological Institute (subdivision) Altai State Technical University of I.I. Polzunov 659305, Russia, Altai Territory, Biysk, Trofimova St., 27

Доктор химических наук, профессор, заведующий кафедрой общей химии и экспертизы товаров

Бийский технологический институт - филиал Алтайского государственного технического университета им. И.И. Ползунова 659305, РФ, Алтайский край, г. Бийск, ул. Трофимова, 27

Post-graduate of the General Chemistry and Goods Examination Department Biysk Technological Institute (subdivision) Altai State Technical University of I.I. Polzunov 659305, Russia, Altai Territory, Biysk, Trofimova St., 27

Аспирант кафедры общей химии и экспертизы товаров Бийский технологический институт - филиал Алтайского государственного технического университета им. И.И. Ползунова 659305, РФ, Алтайский край, г. Бийск, ул. Трофимова, 27 